\title{
„Wieczór” Edwarda Żebrowskiego - autorska kopia
}

Images vol. X/no. 19

Poznań 2012 ISSN 1731-450X

Już pobieżne spojrzenie na realizowaną w łódzkiej Filmówce etiudową twórczość Edwarda Żebrowskiego (wtedy jeszcze Edwarda Bernsteina) musi wyłowić obecną w tych kilku filmach, a najpełniej w Wieczorze (1964), fascynację reżysera dziełami o dwa lata tylko od niego starszego Romana Polańskiego, który po sukcesie Noża w wodzie (1962) właśnie opuścił Polskę. Nawiązania są całkowicie nieskrępowane, nawet można by rzec - ostentacyjne.

Sam problem odwoływania się przez młodych reżyserów - czy wręcz adeptów reżyserii, realizujących swoje projekty w ramach zinstytucjonalizowanej edukacji filmowej - do twórczości już istniejącej, mniej lub bardziej znanej, ma z pewnością złożony charakter. Rzecz jasna zjawisko to wydaje się naturalne, a na ogół nawet konieczne; przecież uczeń pozostaje pod wpływem wybranego przez siebie mistrza. Ale to w żadnym razie nie wyczerpuje tematu. Należy tu oddzielić świadome, $\mathrm{w}$ rozmaity sposób motywowane zabiegi stylizatorskie, czy po prostu użycie cytatów, od nieujawnianego, czasem nie całkiem świadomego wyzyskania na różnych poziomach filmowego tworzywa charakterystycznych właściwości indywidualnego stylu. Niewątpliwie, kiedy spojrzy się na historię kina, samo zjawisko w obu swoich odmianach - podlega zmienności diachronicznej, zarówno pod względem intensywności występowania, jak i jego artystycznej dopuszczalności, a co za tym idzie - również oceny. Ale też każdy przypadek może być rozpatrywany osobno. Szczególnie wtedy, gdy patrzy się na niego z perspektywy dojrzałej twórczości - jak to ma miejsce w odniesieniu do Żebrowskiego.

Wieczór na pierwszy rzut oka wygląda jak wykonana w mikroskali (film trwa trzynaście minut) reprodukcja owianego oskarową sławą (pierwsza nominacja dla polskiego kina) Noża w wodzie. Zbliżona struktura fabularna, problematyka, postacie, czas, przestrzeń, rekwizyty, a nawet ten sam aktor w bliźniaczej roli - Leon Niemczyk jako mąż i kierowca - wszystkie te elementy zdają się potwierdzać wstępne wrażenie. Można by się zastanowić, czy nie byłoby zasadne pytanie o sens tego ćwiczenia. A może miało ono na celu nakręcenie tego samego filmu, tylko w zdecydowanie mniejszym formacie? Takie zadanie byłoby przecież, jeśli powiodłaby się jego realizacja, niezwykłym popisem rzemieślniczej sprawności. A jednak, znając postawę i drogę artystyczną Edwarda Żebrowskiego, trudno uwierzyć, żeby szczególnie mu na tym zależało. Czy więc rzeczywiście mamy do czynienia ze swoistą kopią dzieła Polańskiego? 
Skoro już doszło do enumeratywnej prezentacji pól ewentualnej tożsamości, to wypada $\mathrm{z}$ wystarczającą dokładnością prześledzić każde z nich z osobna. Niewykluczone zresztą, że w trakcie takiej analizy pojawią się jeszcze inne pola, dotychczas ukryte.

Co się więc tyczy struktury fabularnej, to trzeba powiedzieć, że ma ona charakter zamknięty. Oba filmy spaja ta sama klamra, którą stanowią sceny jazdy samochodem. W każdej z nich widzimy parę małżonków $\mathrm{z}$ pewnym już stażem, siedzących na przednich fotelach i prowadzących czasem trochę mniej, czasem bardziej ożywioną rozmowę. Sceny początkowe i końcowe niewiele się od siebie różnią, tak jakby między nimi działy się rzeczy nieważne, jakby nie nastąpiła żadna zmiana i utrzymane zostało wyjściowe status quo. W obu przypadkach to czysty pozór, gdyż w obu dokonują się rzeczy podobnej natury.

Struktura Noża $w$ wodzie oparta jest na zasadzie trójkąta. Do pary małżonków dołącza młody autostopowicz, burząc całkowicie ład. Niedzielny wyjazd na żagle staje się teatrem rywalizacji, a w końcu i walki między spontaniczną, witalną, swobodną młodością a statycznością wieku średniego, jego siłą zawartą głównie w fakcie posiadania rzeczy i ludzi, oraz pewnością siebie. Co innego Wieczór, tu nie ma studenta, nie ma agresji, ani iście samczych popisów. Ale trójkąt wszakże pozostaje. Jego trochę niezauważalnym wierzchołkiem jest para młodych ludzi, którą mężczyzna widzi nad jeziorem. Pokazując się w ledwie półminutowej sekwencji, pełni ona funkcję, która u Polańskiego była udziałem autostopowicza. Choć nie następuje tu żadne starcie, ba, nie ma nawet kontaktu - para nie dostrzega intruza - to przecież efekt jest równie dojmujący. Mężczyzna musi zaznać goryczy porażki, upokorzenia, a powrót do sytuacji wyjściowej obarczony jest ciężarem doświadczenia bolesnego dla obojga małżonków. Rola kobiety w filmie Polańskiego - choćby dzięki faktowi poddania się erotycznemu pragnieniu - jest nieco mniej bierna, ale nie jest to różnica elementarna.

Dużo istotniejszą staje się z całą pewnością wspomniana rezygnacja Żebrowskiego z udramatyzowania relacji mężczyzny z napotkaną parą. Już w tym momencie zaznaczyła się dość typowa dla jego późniejszej twórczości strategia łagodzenia sytuacji konfliktowych na rzecz poprowadzenia wyostrzonego, zdystansowanego dyskursu, strategia, chciałoby się rzec, trochę antyfilmowa. To jednak, co jest antyfilmowe w myśl ogólnie przyjętych zasad rzemiosła, nie musi przecież takim pozostać w odniesieniu do konkretnego, osobnego twórcy $\mathrm{z}$ jego niepowtarzalnym podejściem do materii kina.

U Żebrowskiego zamiast młodzieńca prowokująco wychodzącego na środek jezdni i w ten sposób zatrzymującego samochód, przed oczami mężczyzny (pamiętajmy o nieco złudnej tożsamości bohaterów, uzyskanej przez tożsamość aktora) pojawia się młoda dziewczyna. Najpierw widzi on tylko jej głowę, ale po chwili dziewczyna wynurza się gwałtownie z wody jeziora i odsłania swą świeżą nagość. To też 
jest prowokacja, choć innego zupełnie rodzaju. Oto bohater skonfrontowany zostaje nie tyle $\mathrm{z}$ żywą postacią, ile $\mathrm{z}$ obrazem tego, co w jego życiu bezpowrotnie minęło, obrazem bardzo wyrazistym, także w przenośni niczym nie osłoniętym. Spuszcza głowę, nie próbuje nawet wyzywać czasu. Pojawienie się chłopca, wspólna zabawa z dziewczyną i wreszcie ułożenie się przez młodych w trawie obrazu tego tylko dopełnia, przywołując jednocześnie akt zbliżenia między kobietą a studentem, jaki dokonuje się u Polańskiego. Energia przekazu skupia się więc w etiudzie na wizualizacji przeżycia wewnętrznego, po trosze subiektywnej (obraz postrzegany przez bohatera), a po trosze obiektywnej (rejestracja jego twarzy w zbliżeniu), nie zaś na budowaniu napięcia wokół relacji interpersonalnej.

Nie znaczy to, aby napięcia między postaciami w ogóle nie było. Przeniesione jest ono jednak wyłącznie na stosunki wewnątrzmałżeńskie. Objawia się w sposób delikatny, podskórny. Właściwie nie wypływa bezpośrednio na powierzchnię. Nie zostaje wyrażone wprost - ani w dialogach, ani w gestach czy mimice. Nie ma śladu po ironicznych i dramatycznych rozmowach małżonków z Noża $w$ wo$d z i e$, ale rezultat mikrozdarzeń jest zbliżony - jeszcze głębsze pogrążenie się każdego $\mathrm{z}$ nich w samotność. W uśmiechach, spojrzeniach i gestach kobiety, pojawiających się przed sekwencją wyprawy nad jezioro czytać trzeba nadzieję, oczekiwanie, pragnienie zbliżenia pomieszane z czającym się i zawsze gotowym do zawłaszczenia jej emocji niepokojem, ujawniającym się choćby poprzez kilkakrotnie w różnych okolicznościach powtórzone pytanie: „Co się stało?”. Czułość, spokój i trochę jakby nadzwyczajna subtelność mężczyzny osłaniają tę samą nadzieję i większą pewność, że wzajemną relację uda się odnowić, że osiągalny jest powrót do początku, do świeżości pierwszych doznań. Po powrocie mężczyzny znad jeziora wszystko staje się w jednej chwili najoczywiściej niemożliwe. A dzieje się tak mimo rzuconej spokojnie odpowiedzi na kolejny już raz wypowiedziane pytanie żony, odpowiedzi brzmiącej po prostu: „Nic”. Napięcie opada, trzeba przyznać, dość gwałtownie, a zakończenie obrazujące klęskę jest już bardzo krótkie i zarazem jasne. Rozmowa o hotelu, znużeniu, malowanie ust przez kobietę w świetle reflektorów przejeżdżających pojazdów, a wreszcie awaria samochodu, poza tym, że odwołują się a rebours do podobnych zdarzeń z początku filmu, nie pozostawiają też żadnej znaczeniowej luki. Wiadomo, jak kończy się opowiedziana w utworze historia, choć oczywiście wiadomo także, że życie bohaterów ma potoczyć się dalej, więc zakończenie nie nosi znamienia całkowitej utraty szans i bezwzględnej katastrofy.

Dawno już wkroczyliśmy na terytorium problematyki omawianych filmów. Teraz właściwie wypada tylko konceptualnie zebrać rozsypane $\mathrm{w}$ dużej obfitości informacje. Podstawowym tematem zarówno w wypadku Polańskiego, jak i Żebrowskiego - staje się zmaganie $\mathrm{z}$ doświadczeniem upływu czasu, zmaganie obarczone podobnym rezultatem - poczuciem klęski i rezygnacją. Czterdziestolatkowie 
mierzą się z dwudziestolatkami (także z samymi sobą sprzed lat). W sposób spektakularny robią to oczywiście mężczyźni. Jeden - ten z Noża $w$ wodzie - przegrywa bardzo widowiskowo po serii starć, w których przecież czasem bywa górą, co może wywoływać w nim nadzieję, objawiającą się nawet trochę komiczną buńczucznością. Drugi rezygnuje od razu. Nie ma złudzeń. Zwiesza głowę i bezwzględnie przerywa podróż w przeszłość, ustępując miejsca prawdziwej młodości. Chroni go to przed śmiesznością i jawnym upokorzeniem, ale nie przed goryczą. Tylko zewnętrznie pozostaje panem sytuacji, $\mathrm{w}$ istocie umyka w głąb samego siebie, zrywając wątłą nić głębszego porozumienia z żoną, uznając być może fakt jej zarysowania się za wykreowany sztucznie, poniekąd wymuszony.

To naprowadza na ważną dla obu utworów kwestię relacji kobiecości i męskości. Powiedziane już zostało, że fabuła czyni bohaterkę Wieczoru bardziej bierną od jej filmowej antenatki. Nie jest ona ani świadkiem zmagań mężczyzny z niezwykłym zjawiskiem nad jeziorem - on poszedł tam samotnie - ani też nic o tych zmaganiach nie wie - wszak nic nie zostało jej powiedziane. Tym bardziej więc nie bierze w nich czynnego udziału. A wszystko to przydarza się kobiecie na żaglówce. Mimo to bohaterka etiudy paradoksalnie wydaje się bardziej obecna w świecie filmowym. Mniejsza o wielokrotnie już komentowane słabe aktorstwo Jolanty Umeckiej (dubbingowanej przez Annę Ciepielewską), choć i ono z pewnością miało wpływ na kształtowanie się procesu twórczego[1]. Rzecz w tym, że Żebrowski jedną krótką sekwencją zwizualizował sam moment konfrontacji z obrazem młodości, resztę filmu zaś oddał we władanie żywiołowi relacji kobiety i mężczyzny. Oglądamy więc żonę, która zaproszona przez męża (np. dwukrotnie powtórzona prośba: „Nie maluj się”) współtworzy aurę powrotu do przeszłości. Najpierw prowokuje rozmowę o ślubie, podczas której niepozbawione ironii wspomnienie zestawia $\mathrm{z}$ wracającym do niej młodzieńczym wyobrażeniem. Potem wykonuje szereg gestów zapraszających mężczyznę do przełamania rutyny, do wkroczenia w rzeczywistą intymność. Decyduje się na obarczoną ryzykiem zranienia i okupioną niepokojem otwartość. $\mathrm{Na}$ rozwiązanie sytuacji nie ma już jednak większego wpływu. Zranienie staje się faktem, a postawa mężczyzny okazuje się decydująca. Choć portret kobiety naszkicowany zostaje $\mathrm{z}$ uwagą, to jednak w Wieczorze pozostajemy w obrębie wrażliwości męskiej. To mężczyzna jest podstawowym podmiotem filmowego dyskursu.

Te współczesne historie odwołują nas bez wątpienia do przestrzeni kulturowego uniwersalizmu, do rzeczywistości Thanatosa i Erosa - właśnie w tej, trochę rzadziej spotykanej hierarchii ważności, a co za tym idzie, także kolejności. Filmowi protagoniści, trochę tak jak Wiktor Ruben z opowiadania Iwaszkiewicza i filmu Wajdy Panny $z$ Wilka, stają wobec znaczącego w życiu momentu, gdy lato przeła- 
muje się ku jesieni i wiele rzeczy tego świata przestaje być dla człowieka osiągalnymi. Obumieranie ciała (ale nie tylko jego) daje o sobie wyraźnie znać. Miłość, zwłaszcza w jej seksualnym wymiarze, ma pełnić rolę swoistego testu dla witalności. Bardzo ważne dla rozpoczęcia tej gry są obecne w każdym $\mathrm{z}$ utworów sceny przebierania się przez kobiety. Test dla obu dojrzałych mężczyzn wychodzi marnie, a niechcianym celem ucieczki staje się widmo końca.

Podczas tej analizy ciągle natrafiamy na elementy pokrewieństwa między postaciami, szczególnie tymi granymi przez Leona Niemczyka. Trochę inaczej jest już, o czym była zresztą mowa, z bohaterkami żeńskimi. Rysuje się jednak jedna pierwszoplanowa różnica między kreacjami ludzkimi z obu filmów. Otóż Polański pokazuje swych bohaterów jako dynamicznych, reagujących spontanicznie i emocjonalnie, czasem znajdujących się na granicy prymitywizmu, nie szukających empatii, introspekcji czy refleksyjnego dystansu. Żebrowski robi coś przeciwnego. Czyni swych protagonistów właśnie refleksyjnymi i zdystansowanymi. Każe im ukrywać emocje, zewnętrznie się im nie poddawać, panować nad ich wyrazem nawet w trudnych momentach, szybko i krytycznie ocenić granice swoich możliwości. Droga do ich wewnętrznego świata okazuje się bardziej pośrednia, skomplikowana. Ich wzajemne stosunki kształtują się tyleż poprzez realne wewnętrzne nastawienie, co pragnienie, grę czy konwencję. Czuły i łagodny mężczyzna oraz rozkwitająca uśmiechem kobieta to nie są prawdziwi bohaterowie tej opowieści, podobnie zresztą jak spokojni, zrównoważeni i mili dla siebie małżonkowie ze sceny finałowej. W istocie to przecież ludzie zawieszeni między lękiem a nadzieją, pełni niepokoju, a potem przełykający gorzki smak niepowodzenia i wstydu.

Zgodnie ze strategią młodego reżysera, unikającego wszakże jako się rzekło - dramatyzowania konfliktów, nie dochodzi w filmie do żadnej, choćby najkrótszej i najbardziej enigmatycznej, rozmowy wyjaśniającej wzajemne relacje bohaterów, formułującej ich wzajemne o sobie opinie oraz wyjawiającej expressis verbis stan ich emocji. A co najmniej trzy takie pojawiają się u Polańskiego. Nie bez przyczyny między obrazem powrotu męża znad wody i jego oznajmieniem, że pomylił miejsce, a zamykającą film sceną samochodową pojawia się wielka elipsa czasowa. Właśnie wtedy taka rozmowa powinna się była odbyć. Nie wiemy zresztą, czy się nie odbyła, ale nie mamy co do tego żadnej wskazówki, ani też żadnego po niej śladu. Nie bez przyczyny też widzimy, jak bohaterowie, a nade wszystko mężczyzna, bez walki ulegają rezygnacji. Wydaje się, że sprawia to ów trzeźwy, racjonalny dystans, od razu każący im realnie ocenić rzeczywistość. dystans tyleż cenny, bo pozwalający uniknąć spektakularnych klęsk, co groźny, gdyż ograniczający szanse na niespodziewane zwycięstwa.

Choć czas i przestrzeń Noża $w$ wodzie oraz Wieczoru nie są zupełnie tożsame, to jednak ich podobieństwo w znacznym stopniu zwraca uwagę na paralelę między utworami, buduje ją po prostu. Jest 
to czas i przestrzeń czasu wolnego, ale raczej weekendu niż wakacji, czas i przestrzeń drogi poza miasto i odnajdywania się w rzeczywistości natury, zdającej się czynić relacje międzyludzkie bardziej autentycznymi, uproszczonymi. Mamy zatem do czynienia $z$ sytuacją szczególną w życiu bohaterów, może nie z doświadczeniem zupełnie wyjątkowym, ale też nie z codziennym.

Czas w filmie Polańskiego wypełnia starożytną regułę jedności, a więc zamyka się $\mathrm{w}$ trakcie jednej doby. Dzieli się on na cztery sekwencje: poranną, dzienną, wieczorną i znów poranną. Przy czym poczucie ciągłości zerwane jest tylko między wieczorem i drugim porankiem, a wynika ze snu bohaterów i nie zaburza poczucia uczestnictwa w całym toku zdarzeń. Widzimy wszystko, co najważniejsze. Otrzymujemy esencję tego, co znaczące dla budowania napięcia i konfliktu. Wszystko, co nie jest temu podporządkowane, umyka. Struktura jest jasna i ściśle realizowana.

Żebrowski z kolei zamyka swoją anegdotę w tytułowej porze dnia, także dnia letniego, być może soboty. Bo o Nożu wiemy z pewnością, że rozgrywa się od niedzielnego do poniedziałkowego poranka. W przypadku leśnej eskapady z etiudy już nie dzieje się jednak tak, że reżyser pozwala zobaczyć wszystko. Wiele trzeba sobie dopowiedzieć. Najwięcej zagadek stawia wspomniana elipsa umieszczona pomiędzy powrotem mężczyzny znad jeziora a jazdą samochodem o zmierzchu. Żebrowski chowa część z tego, co mogłoby być wydobyte, chłodząc w ten sposób temperaturę dramatu, prowokując imaginację widzów, ale, co ważne, nie gubiąc czytelności. Podobieństwo i tym razem nosi więc w sobie znaczącą różnicę.

Podobnie zresztą jak w przypadku plenerowej scenerii filmów. Oczywiście w obu na bardzo podobnych zasadach funkcjonuje zamknięta kapsuła samochodowej kabiny, w której przodzie zajmują miejsce małżonkowie i z której wychodzą na świat. Ale już poza nią pojawia się odmienność, której sens można by wyrazić w opozycji zamknięte-otwarte. U Polańskiego auto porusza się drogą wśród pól i łąk. Potem zaś bohaterowie przesiadają się do łodzi, którą płyną po wodach dużego, mazurskiego jeziora. Konsekwentnie więc pozostajemy w przestrzeni bardzo rozległej, przejrzystej, choć przy tym odludnej. Poza trójką protagonistów w oku kamery nie pojawia się bowiem żaden człowiek ani też żaden pojazd. W Wieczorze natomiast nie ma takiego momentu, w którym opuścilibyśmy las. Jego ściany rozpinają się wzdłuż drogi, na której panuje zwykły ruch. Pośród niego ukrywa się dukt, którym mężczyzna i kobieta zmierzają do miejsca biwaku, położonego w jego głębi. Poprzez jego utrudniającą poruszanie się, bujną gęstwinę bohater przedziera się na brzeg jeziora. Krótka scena nad, niewielkim zresztą, leśnym jeziorem jest jedyną rozszerzającą nieco perspektywę widzenia, dającą oddech. Przez kilkanaście minut projekcji znajdujemy się $\mathrm{w}$ przestrzeni jednocześnie plenerowej i nieco klaustrofobicznej, przestrzeni dusznej, nieprzeniknionej, niepokojącej. Rzecz jasna nie pozostaje to bez wpływu na wyraz filmu. 
Dzięki takiemu ukształtowaniu materii pleneru pogłębione zostaje poczucie zagadkowości, niedookreślenia i niepełnej jawności opowiedzianej historii, szczególnie w sferze emocji. Żebrowski także i w ten sposób funduje świat, wydawałoby się bardzo zbliżony, a w istocie dość zasadniczo różny od świata Noża $w$ wodzie.

Na pewno nie tak zasadnicze odmienności tyczą się uniwersum rekwizytów. Staje się ono bardzo silnie akcentowanym elementem nawiązania. Samochody nie są ani tej samej marki, ani tej samej wartości. Nie są nawet w podobnym stanie technicznym (ten z Wieczoru dwa razy ulega awarii). A jednak wszystko to ma drugorzędne znaczenie wobec funkcji, jaką pełnią sceny rozgrywające się w ich wnętrzach. Drugorzędne znaczenie wiąże się też z częściowo różnym charakterem sprzętu turystycznego, jakiego używają bohaterowie. Bo nawet jeśli płótno żagla zmienia się w płótno namiotu, dmuchanie krokodyla $\mathrm{w}$ dmuchanie materaca, płetwy w klapki, posiłki na pokładzie i pod pokładem w niedoszłą kolację na trawie, to istota pozostaje niemal tożsama. Pieczołowitość i wprawa, z jaką szczególnie mężczyźni obchodzą się z owym sprzętem, sankcjonuje ich siłę i wartość, a przy tym pozwala im zachować azyl, w którym mogą się zaszyć. W związku z tym niezwykle ciekawy jest moment, kiedy w Wieczorze żona poprzez oko obiektywu ogląda męża szykującego sprzęt wędkarski.

Taka szczegółowa analiza paraleli między filmem Polańskiego a etiudą Żebrowskiego mogłaby się jeszcze poszerzać i pogłębiać. Rzecz jednak nie w tym, by sporządzić kompletny inwentarz podobieństw, lecz, by pokazać ich charakter i znaleźć ich sens. A to w zasadzie już się udało. Autor Szansy w pierwszym swoim większym utworze, jeszcze studenckim, tak obficie czerpiąc z niedawnego dokonania niewiele starszego kolegi, odsłonił podstawowe zręby własnego stylu artystycznego. Nóż $w$ wodzie stał się dla niego nie tyle protezą, która miała ukryć brak doświadczenia czy inwencji, ile wygodnym punktem odniesienia do pierwszej krystalizacji własnego myślenia o filmie. Dlatego właśnie wszelkie różnice w kreacji ekranowego świata, o których była przecież mowa, mają swoje wyjaśnienie w konsekwentnie układającej się strategii. Można by ją streścić w kilku krótkich punktach: ucieczka od klasycznej dramaturgii, opartej na wyrazistym konflikcie, minimalizowanie i ukrywanie emocji, stosowanie niedopowiedzeń, a więc wymuszanie aktywności widza w odtwarzaniu zdarzeń i motywacji, pewien brak zaufania do słowa jako bezpośredniego nośnika treści. 